\title{
The Experimental Analysis of College Hierarchical Badminton Teaching
}

\author{
Fanwei Meng a ${ }^{a}$ Xiaohui Liu ${ }^{b}$ \\ Changchun University of science and technology, Changchun 130000, China \\ a13742883@qq.com, b28367449@qq.com
}

\begin{abstract}
Hierarchical teaching is a teaching model by which teachers take the appropriate method to teach according to the different levels and personalities of students. Taking the 200 students of tennis teaching class as respondents, this analysis makes a research about hierarchical teaching by means of document analyses, experiments, observations, and questionnaire surveys. Therefore, we can get a conclusion that the hierarchical teaching has an important effect on students' individual quality and sports level, and also plays a positive role in the quality and the efficiency of college badminton teaching.
\end{abstract}

Keywords: Hierarchical teaching; Sports level Enthusiasm; Teaching quality.

\section{Introduction}

At present, the teaching method in college physical education teaching adopts hierarchical cooperation is after the practice teaching reform a new teaching mode, this kind of teaching mode to carry out the teaching according to their aptitude. Although the hierarchical cooperative teaching method in physical education teaching in some areas have some lessons, but in the badminton teaching the application is still in exploring stage. University sports departments in is one of the main teaching form, this form of teaching is an important content of physical education reform, according to the requirement of the reform, the reform of teaching method must have certain innovation.

\section{The Experiment Design}

\subsection{The Purpose of Study}

Hierarchical teaching refers to a kind of class-divided teaching according to students' individual differences and ability to accept things when the teacher arranges teaching content, teaching methods, and teaching measures. The purpose of this experiment is mainly a different teaching model by making comparisons between different models of college badminton teaching.

\subsection{The Object of Study}

The study selects 200 students from 4 classes of tennis of Grade 2015, and divides them into 2 groups (A/B). Group A takes the small class teaching as the experimental group while Group B takes the big class teaching as the contrast group.

\subsection{The Study Methods}

(1)Document analyses: First, we make it clear about the way to carry out the hierarchical teaching by searching for, collecting and studying the related documents from the theses, journals, books and websites of the school libraries and computers to make sure the positive effect that the hierarchical teaching takes to students. (2) Experiments: Before the class, we need make a test about the basic skills (backhand ground stroke, serve a ball, etc.) of students from experimental group and contrast group. And then teach the students from experimental group with hierarchical teaching according to their different levels and personalities while teach the students from contrast group with the traditional big class teaching model.(3) Observations: In the regular period of the same term, we'll observe students' condition in class including their presence, enthusiasm and skills, and we'll make a comprehensive assessment to their classroom instruction effect at the end of the term. (4Questionnaire surveys: For surveying students from the two groups, we'll make a questionnaire about fundamental knowledge, skills of badminton and satisfaction with the class teaching. 
Table 1 In the two groups before and after the experiment the students forehand number 60 seconds

\begin{tabular}{|c|c|c|c|c|c|c|c|c|}
\hline & $\begin{array}{c}\text { The } \\
\text { total } \\
\text { number } \\
\text { of } \\
\text { people }\end{array}$ & $\begin{array}{c}\text { The } \\
\text { average } \\
\text { number } \\
\text { before } \\
\text { teaching }\end{array}$ & $\begin{array}{c}\text { The } \\
\text { average } \\
\text { number of } \\
\text { after } \\
\text { teaching }\end{array}$ & $\begin{array}{c}\text { The highest } \\
\text { number } \\
\text { before } \\
\text { teaching }\end{array}$ & $\begin{array}{c}\text { The highest } \\
\text { number } \\
\text { after } \\
\text { teaching }\end{array}$ & $\begin{array}{c}\text { The } \\
\text { minimum } \\
\text { number } \\
\text { before } \\
\text { teaching }\end{array}$ & $\begin{array}{c}\text { After } \\
\text { teaching } \\
\text { the lowest } \\
\text { number }\end{array}$ & \\
\hline $\begin{array}{c}\text { Group A } \\
\text { (experimental } \\
\text { group) }\end{array}$ & 100 & 33.0 & 34.6 & 32 & 34 & 27 & 25 & 18 \\
\hline $\begin{array}{c}\text { Group B } \\
\text { control } \\
\text { group) }\end{array}$ & 100 & 29.2 & 28.4 & 31 & 32 & 19 & 18 \\
\hline
\end{tabular}

\section{The Study Results}

Table 1 makes a comparison of the number of forehand strokes of the two group students in 60 seconds before and after the class teaching. It can be seen from the table that both the average number and the max number of hitting the ball of the experimental group have increased after the teaching. However, for the contrast group, although the max number of hitting the ball has increased to some extent, the average number of hitting the ball has dropped actually.

The max number of hitting the ball of the experimental group have increased after the teaching. However, for the contrast group, although the max number of hitting the ball has increased to some extent, the average number of hitting the ball has dropped actually.

Table 2 In the two groups before and after the experiment the students backhand number 60 seconds

\begin{tabular}{|c|c|c|c|c|c|c|c|}
\hline & $\begin{array}{c}\text { The } \\
\text { total } \\
\text { number } \\
\text { of } \\
\text { people }\end{array}$ & $\begin{array}{c}\text { The average } \\
\text { number } \\
\text { before } \\
\text { teaching }\end{array}$ & $\begin{array}{c}\text { The average } \\
\text { number of } \\
\text { after } \\
\text { teaching }\end{array}$ & $\begin{array}{c}\text { The highest } \\
\text { number } \\
\text { before } \\
\text { teaching }\end{array}$ & $\begin{array}{c}\text { The highest } \\
\text { number } \\
\text { after } \\
\text { teaching }\end{array}$ & $\begin{array}{c}\text { The } \\
\text { minimum } \\
\text { number } \\
\text { before } \\
\text { teaching }\end{array}$ & $\begin{array}{c}\text { After } \\
\text { teaching the } \\
\text { lowest } \\
\text { number }\end{array}$ \\
\hline $\begin{array}{c}\text { Group A } \\
\text { (experimental } \\
\text { group) }\end{array}$ & 100 & 32.1 & 33.4 & 33 & 35 & 27 & 24 \\
\hline $\begin{array}{c}\text { Group B } \\
\text { (control } \\
\text { group) }\end{array}$ & 100 & 27.6 & 28.1 & 31 & 32 & 26 & 25 \\
\hline
\end{tabular}

Table 2 makes a comparison of the number of backhand strokes of the two group students in 60 seconds before and after the class teaching. It can be seen from the table that both the average number and the max number of hitting the ball of the experimental group have obviously increased much more than that of the contrast group after the teaching. Meanwhile, the min number of hitting the ball of the contrast group drops from 27 to 24 , while for the experimental group, it just drops from 26 to 25 .

Table 3 two groups of students to the class

\begin{tabular}{|c|c|c|c|c|c|}
\hline & $\begin{array}{c}\text { The total } \\
\text { number of } \\
\text { people }\end{array}$ & $\begin{array}{c}\text { Not absent from } \\
\text { class }\end{array}$ & $\begin{array}{c}\text { Absent from } \\
\text { class one }\end{array}$ & Absent from class two & $\begin{array}{c}\text { Absent more } \\
\text { than 3 times }\end{array}$ \\
\hline $\begin{array}{c}\text { Group A } \\
\text { (experimental } \\
\text { group) }\end{array}$ & 100 & 89 & 7 & 3 & 1 \\
\hline $\begin{array}{c}\text { Group B (control } \\
\text { group) }\end{array}$ & 100 & 73 & 6 & 12 & 9 \\
\hline
\end{tabular}

Table 3 shows the presence situation of the two group students in a semester. It can be seen obviously that the number of the students from the contrast group who are absent from class more than 3 times is far more than that of the experimental group. Simultaneously, the number of the 
students from the experimental group who never miss the class is 89 , while for the contrast group, it is only 73.

Table 4 students to class satisfaction

\begin{tabular}{|c|c|c|c|c|c|}
\hline & $\begin{array}{c}\text { The total } \\
\text { number of } \\
\text { people }\end{array}$ & quite satisfied & satisfaction & general & Unsatisfactory \\
\hline $\begin{array}{c}\text { Group A } \\
\text { (experimental } \\
\text { group) }\end{array}$ & 100 & 80 & 13 & 7 & 0 \\
\hline $\begin{array}{c}\text { Group B (control } \\
\text { group) }\end{array}$ & 100 & 21 & 50 & 19 & 10 \\
\hline
\end{tabular}

Table 4 indicates students' classroom instruction satisfaction through the questionnaire survey statistics. From the table, we can see that $80 \%$ students of group are very satisfied with the classroom instruction pattern, but for group B it is only $21 \%$. Simultaneously, none of the experimental group is unsatisfied with its classroom instruction pattern, but for the contrast group, there are 10 students.

\section{Conclusion}

(1)Hierarchical small-class teaching is based on different levels of competency and their aspiration. It not only improves enthusiasm of students, but also makes all levels of students establish goals and join in the classroom activities independently according to their own different situations. It can help students improve their technical skills and comprehensive performance, strengthen the communication between teachers and students, promote the friendly relationship between teachers and students, and build a good teaching environment.

(2)Hierarchical small-class teaching has the strong pertinence. For classroom teaching to different levels and different types of students, it has different teaching requirements and teaching methods, which not only can effectively improve the students' self-confidence, but also can make the students strengthen their own sense of achievement in the classroom learning. At the same time, teachers choose different ways of education that can not only make students get personalized development, but also can effectively improve the teaching quality.

(3)Through this experiment study we can find that using the hierarchical teaching method in badminton teaching can not only stimulate the students' learning enthusiasm, improve the students' physical quality and athletic ability, but also sharply reduce the phenomenon of students' absence from class and enhance the students' satisfaction with the classroom instruction.

\section{References}

[1] Yu Wentao. Badminton basic optimization technology experiment teaching method research [D]. Beijing sport university, 2013.

[2] Zhu Guanzheng. Badminton public physical education in common colleges and universities teaching design and the empirical research [D]. Chengdu sports institute, 2014.

[3] Qin Yu. "Stratified teaching" in the sports education professional table tennis in experimental research [D]. Chengdu sports institute, 2014.

[4] Xu Ivan. "Layers" teaching pattern in the badminton technology courses experimental research [D]. Chengdu sports institute, 2015.

[5] Tan Junhui. "Layered lifting" teaching method in the ordinary university badminton teaching application research [j] sports world (below the ten-day), 2013 (11): $116 \sim 117$.

[6] Back into the brightness. The application of hierarchical teaching method in university teaching research [j]. Journal of Shandong institute of agricultural engineering, 2014 (03): $187 \sim 188$ 